\title{
Uncoupling of ATP-depletion and cell death in human dopaminergic neurons
}

\author{
Dominik Pöltl $^{\mathrm{a}, \mathrm{b}, 1}$, Stefan Schildknecht ${ }^{\mathrm{a}, 1}$, Christiaan Karreman ${ }^{\mathrm{a}}$, Marcel Leist ${ }^{\mathrm{a}, *}$ \\ ${ }^{a}$ Doerenkamp-Zbinden Chair of In Vitro Toxicology and Biomedicine, University of Konstanz, PO Box M657, D-78457 Konstanz, Germany \\ ${ }^{\mathrm{b}}$ Konstanz Research School Chemical Biology, University of Konstanz, Germany
}

\begin{abstract}
A B S T R A C T
The mitochondrial inhibitor 1-methyl-4-phenylpyridinium $\left(\mathrm{MPP}^{+}\right)$is the toxicologically relevant metabolite of 1-methyl-4-phenyltetrahydropyridine (MPTP), which causes relatively selective degeneration of dopaminergic neurons in the substantia nigra. Dopaminergic LUHMES cells were used to investigate whether ATP-depletion can be uncoupled from cell death as a downstream event in these fully post-mitotic human neurons. Biochemical assays indicated that in the homogeneously differentiated cell cultures, $\mathrm{MPP}^{+}$was taken up by the dopamine transporter (DAT). MPP ${ }^{+}$then triggered oxidative stress and caspase activation, as well as ATP-depletion followed by cell death. Enhanced survival of the neurons in the presence of agents interfering with mitochondrial pathology, such as the fission inhibitor Mdivi-1 or a Bax channel blocker suggested a pivotal role of mitochondria in this model. However, these compounds did not prevent cellular ATP-depletion. To further investigate whether cells could be rescued despite respiratory chain inhibition by $\mathrm{MPP}^{+}$, we have chosen a diverse set of pharmacological inhibitors well-known to interfere with $\mathrm{MPP}^{+}$toxicity. The antioxidant ascorbate, the iron chelator desferoxamine, the stress kinase inhibitor CEP1347, and different caspase inhibitors reduced cell death, but allowed ATP-depletion in protected cells. None of these compounds interfered with $\mathrm{MPP}^{+}$accumulation in the cells. These findings suggest that ATP-depletion, as the initial mitochondrial effect of $\mathrm{MPP}^{+}$, requires further downstream processes to result in neuronal death. These processes may form self-enhancing signaling loops, that aggravate an initial energetic impairment and eventually determine cell fate.
\end{abstract}

\section{Introduction}

Degeneration of dopaminergic neurons projecting from the substantia nigra to the striatum is a key pathological feature of Parkinson's disease (PD). It may also be triggered by a variety of chemicals such as the pesticides rotenone and paraquat, the occupational hazardous agent manganese, or 1-methyl-4-phenyltetrahydropyridine (MPTP) (Bezard and Przedborski, 2011; Di Monte, 2003). The latter agent has been discovered to trigger a PDlike state in users of illicit drugs containing such contaminations (Langston et al., 1983). MPTP has been used since then to trigger dopaminergic degeneration in primates, rodents, fish, and invertebrates in vivo. Its active metabolite 1-methyl-4-phenylpyridinium $\left(\mathrm{MPP}^{+}\right)$has been used for related experiments in vitro (Braungart et al., 2004; Nicotra and Parvez, 2002; von Bohlen und Halbach, 2005). $\mathrm{MPP}^{+}$is transported into dopaminergic neurons by

\footnotetext{
* Corresponding author. Tel.: +49 7531 885037; fax: +49 7531885039 E-mail addresses: Dominik.Poeltl@uni-konstanz.de (D. Pöltl), Stefan.Schildknecht@uni-konstanz.de (S. Schildknecht),

Christiaan.Karreman@uni-konstanz.de (C. Karreman),

Marcel.Leist@uni-konstanz.de (M. Leist).

${ }^{1}$ These authors contributed equally to this work.
}

the dopamine transporter (DAT), and further accumulates in mitochondria, where it inhibits mitochondrial complex I (Bezard and Przedborski, 2011; Lotharius and Brundin, 2002).

Different lines of evidence point to a role of mitochondria in PD. For instance, mutations in genes coding for six mitochondriaassociated proteins, namely parkin, PINK1 (PTEN-induced putative kinase 1), DJ-1, alpha-synuclein, LRRK2 and Omi/HTRA2, cause familial forms of PD. Furthermore, complex I activity is decreased also in non-familial forms of the disease (DiMauro and Schon, 2008; Schapira, 2010). It is widely accepted that $\mathrm{MPP}^{+}$mimics some of the effects observed in PD by inhibiting mitochondrial complex I (Greenamyre et al., 2001), and that the reduced ATP levels parallel cytotoxicity (Chan et al., 1991; Richardson et al., 2007; Stephans et al., 2002).

However, mitochondria may induce or accelerate, or even protect from cell death. For instance, mitochondrial inhibition by $\mathrm{MPP}^{+}$can be well tolerated by some types of neurons, and may even increase their resistance to apoptotic insults (Volbracht et al., 1999). At the same time, it may highly increase their sensitivity to a second, excitotoxic insult (Leist et al., 1998). The complex role of mitochondria may be explained by their involvement in acting both as a trigger and as a target of multiple death signaling loops, such as caspase activation, generation of oxygen radicals, and 
stress kinase signaling (Huber et al., 2011; Orrenius et al., 2011; Schon and Przedborski, 2011). Thus, the relationship of mitochondrial respiratory inhibition and cell death may be dependent on the type of cell investigated, and also on several specific conditions. Indeed, $\mathrm{MPP}^{+}$affects rat dopaminergic neurons less than their murine counterparts, and it has been speculated that the difference is related to a different ability to cope with impaired energy metabolism (Sundstrom and Samuelsson, 1997). Furthermore, $\mathrm{MPP}^{+}$has virtually no toxic effect on the tuberoinfundibular dopaminergic system (Behrouz et al., 2007), and shows pronounced selectivity for nigrostriatal neurons over mesolimbic dopaminergic neurons, despite similar uptake (Hung et al., 1995). Differential expression of protective factors such as BDNF (Hung and Lee, 1996) or other signaling proteins such as GIRK2, PACAP, and IGF-1 (Chung et al., 2005) has been suggested as a potential cause for the differences in sensitivity.

The above findings suggest that various dopaminergic cell populations may survive exposure to $\mathrm{MPP}^{+}$to a different extent, despite a similar initial ATP-depletion. To test this in a simplified experimental model situation, we addressed the question, whether dopaminergic neuron degeneration and ATP-depletion could be dissociated in the presence of pharmacological inhibitors of cell death. The literature data on the correlation of ATP-depletion and cell death under conditions of pharmacological intervention are relatively scarce, as the measurement of ATP is difficult in primary dopaminergic neurons or in vivo. Therefore, we made use of LUHMES neurons (Lotharius et al., 2005; Scholz et al., 2011), which form homogeneous cultures and thus allow biochemical assays. Moreover, they express the machinery for dopamine synthesis and transport, which is required for the susceptibility to low concentrations of $\mathrm{MPP}^{+}$. In this model, we used a broad set of well-established pharmacological inhibitors to block dopaminergic cell death, and to examine the role of cellular ATP in cell survival.

\section{Materials and methods}

\subsection{Materials}

LUHMES cells were cultured in Nunclon (Nunc, Roskilde, Denmark) plastic cell culture flasks and multi-well plates, precoated with $50 \mu \mathrm{g} / \mathrm{ml}$ poly-L-ornithine and $1 \mu \mathrm{g} / \mathrm{ml}$ fibronectin (Sigma-Aldrich, St. Louis, MO, USA) in $\mathrm{H}_{2} \mathrm{O}$ for $3 \mathrm{~h}$. Proliferation medium consisted of Advanced Dulbecco's modified Eagle's medium/F12, $1 \times \mathrm{N}-2$ supplement (Invitrogen, Karlsruhe, Germany), $2 \mathrm{mM}$ L-glutamine (Gibco, Rockville, MD, USA) and $40 \mathrm{ng} / \mathrm{ml}$ recombinant basic fibroblast growth factor (R\&D Systems, Minneapolis, MN, USA). Differentiation medium consisted of Advanced Dulbecco's modified Eagle's medium/F12, $1 \times \mathrm{N}-2$ supplement, $2 \mathrm{mM}$ L-glutamine, $1 \mathrm{mM}$ dibutyryl cAMP(Sigma-Aldrich), $1 \mu \mathrm{g} / \mathrm{ml}$ tetracycline (Sigma-Aldrich) and $2 \mathrm{ng} / \mathrm{ml}$ recombinant human GDNF (R\&D Systems).

Mdivi-1 (3-(2,4-dichloro-5-methoxyphenyl)-2,3-dihydro-2thioxo-4 $(1 \mathrm{H})$-quinazolinone) was obtained from Sigma-Aldrich, Bax channel inhibitor (3,6-dibromo- $\alpha$-(1-piperazinylmethyl)-9Hcarbazole-9-ethanol dihydrochloride) from Tocris Bioscience (Ellisville, MO, USA), zVAD-OMe-fmk and Q-VD-OPh from Calbiochem (San Diego, CA, USA). Ascorbic acid, desferoxamine mesylate and $\mathrm{MPP}^{+}$ were obtained from Sigma-Aldrich. CEP1347 (3,9-bis[(ethylthio)methyl]-K-252a) was obtained by chemical modification of K-252a (Calbiochem) according to standard methods (Kaneko et al., 1997).

\subsection{LUHMES differentiation}

LUHMES are conditionally immortalized neurons with dopaminergic characteristics (Lotharius et al., 2005). The cells were derived by conditional immortalization of female human embry- onic ventral mesencephalic cells and subsequent clonal selection. LUHMES cells were grown at $37{ }^{\circ} \mathrm{C}$ in a humidified $95 \%$ air $/ 5 \% \mathrm{CO}_{2}$ atmosphere. Proliferating cells were enzymatically dissociated with trypsin $\left(138 \mathrm{mM} \mathrm{NaCl}, 5.4 \mathrm{mM} \mathrm{KCl}, 6.9 \mathrm{mM} \mathrm{NaHCO}_{3}, 5.6 \mathrm{mM}\right.$ D-glucose, $0.54 \mathrm{mM}$ EDTA, $0.5 \mathrm{~g} / 1$ trypsin from bovine pancreas type-II-S; Sigma-Aldrich) and passaged $1: 10$ at $80 \%$ confluency. For differentiation, $8 \times 10^{6}$ LUHMES were seeded into a T175 flask in proliferation medium and differentiation was started after $24 \mathrm{~h}$, i.e. on day 0 (d0), by changing to differentiation medium. After 2 days of cultivation in culture flasks, cells were trypsinized and seeded into PLO/fibronectin pre-coated multi-well plates.

\subsection{Cell viability}

\subsubsection{Resazurin metabolization assay}

Cell viability was assessed after $72 \mathrm{~h}$ with the resazurin assay (Schildknecht et al., 2009) using $5 \mu \mathrm{g} / \mathrm{ml}$ resazurin sodium salt (Sigma-Aldrich).

\subsubsection{Lactate dehydrogenase ( $L D H)$ release assay}

LDH activity was detected separately in the supernatant and cell homogenate (Latta et al., 2000). LDH release was expressed in percent as ratio of $\mathrm{LDH}_{\text {supernatant }} / \mathrm{LDH}_{\text {total }}$. Cells were lysed in PBS/ $0.5 \%$ Triton $\mathrm{X}-100$ for $20 \mathrm{~min}$. Then, $10 \mu \mathrm{l}$ of sample was added to $200 \mu \mathrm{l}$ of reaction buffer containing NADH $(100 \mu \mathrm{M})$ and sodium pyruvate $(600 \mu \mathrm{M})$ in sodium phosphate buffer adjusted to $\mathrm{pH} 7.4$ by $40.24 \mathrm{mM} \mathrm{K}_{2} \mathrm{HPO}_{4}$ and $9.7 \mathrm{mM} \mathrm{KH}_{2} \mathrm{PO}_{4}$ buffer. Absorption at $340 \mathrm{~nm}$ was detected at $37^{\circ} \mathrm{C}$ in $1 \mathrm{~min}$ intervals over a period of $20 \mathrm{~min}$.

\subsubsection{Staining with vital dyes}

Cells were stained for 5 min with $0.5 \mu \mathrm{M}$ SYTOX (membraneimpermeable green fluorescent dye) and $0.5 \mu \mathrm{g} / \mathrm{ml} \mathrm{H}-33342$ (membrane-permeable blue-fluorescent dye). Images from randomly selected fields were taken, and the number of nuclei, that were SYTOX-positive or that showed condensed chromatin, were scored by three observers blinded to the experimental conditions (Hirt and Leist, 2003). Data were from $>400$ cells from at least 3 different wells.

\subsection{ATP assay}

Cells grown in 24-well plates were lysed in PBS-buffer containing $0.5 \%$ phosphatase inhibitor cocktail 2 (Sigma) and boiled at $95{ }^{\circ} \mathrm{C}$ for $10 \mathrm{~min}$. Following centrifugation at $10,000 \times \mathrm{g}$ for $5 \mathrm{~min}$ for the removal of cell debris, protein content in the supernatant was determined and adjusted to equal amounts, samples were then diluted $1: 10$ in $\mathrm{PBS} / 0.5 \%$ phosphatase-inhibitor buffer. For the detection of ATP levels, a commercially available ATP assay reaction mixture (Sigma-Aldrich), containing luciferin and luciferase, was used (Volbracht et al., 1999). Fifty microliters of adjusted sample and $100 \mu \mathrm{l}$ of assay-mix were added to a white half-area 96-well plate. Standards were prepared by serial dilutions of ATP disodium salt hydrate (Sigma-Aldrich) to obtain concentrations ranging from $1000 \mathrm{nM}$ to $7.8 \mathrm{nM}$.

\subsection{Western-blot analysis}

Cells were lysed in RIPA-buffer (50 mM Tris-base, $150 \mathrm{mM}$ $\mathrm{NaCl}, 1 \mathrm{mM}$ EDTA, $0.25 \%$ sodium deoxycholate, $1 \% \mathrm{NP} 40,1 \mathrm{mM}$ $\mathrm{Na}_{3} \mathrm{VO}_{4}, 50 \mathrm{mM} \mathrm{NaF}, \mathrm{pH}$ 7.5). Determination of protein concentration was performed by using a BCA protein assay kit (Pierce/ Thermo Fisher Scientific, Rockford, IL, USA). Twenty-five micrograms of total protein were loaded onto $12 \%$ SDS gels. Proteins were transferred onto nitrocellulose membranes (Amersham, Buckinghamshire, UK). Loading and transfer were checked by 
brief Ponceau staining. Washed membranes were blocked with 5\% milk in PBS-Tween (0.1\%) for $1 \mathrm{~h}$ (Falsig et al., 2004). Primary antibodies were incubated at $4{ }^{\circ} \mathrm{C}$ over night. Following washing steps with PBS-Tween (0.1\%), horseradish peroxidase-conjugated secondary antibodies were incubated for $1 \mathrm{~h}$ at RT. For visualization, ECL Western blotting substrate (Pierce/Thermo Fisher Scientific) was used. The anti-TH antibody was obtained from Chemicon/Millipore (mouse, 1:5000), and anti GAPDH antibody was obtained from Sigma-Aldrich (mouse, 1:5000). The secondary anti-mouse HRP antibody (1:5000) was obtained from Jackson Immuno Research (Suffolk, UK).

\subsection{Immunocytochemistry}

Cells were grown on $10 \mathrm{~mm}$ glass cover slips (Menzel, Braunschweig, Germany) in 24-well plastic cell culture plates $\left(\right.$ Nunclon $\left.{ }^{\mathrm{TM}}\right)$. Following treatment, cells were fixed with $4 \%$ paraformaldehyde for $20 \mathrm{~min}$ at $37^{\circ} \mathrm{C}$ and washed with PBS. After blocking with $1 \%$ BSA (Calbiochem) for $1 \mathrm{~h}$, primary antibodies were incubated in PBS-Tween $\left(0.1 \%\right.$ ) at $4{ }^{\circ} \mathrm{C}$ over night. Secondary antibodies were incubated for $45 \mathrm{~min}$ at RT. Hoechst $(1 \mu \mathrm{g} / \mathrm{ml})$ was added for $15 \mathrm{~min}$ prior to the final washing step. For visualization, an Olympus IX81 microscope (Hamburg, Germany) equipped with a F-view CCD camera was used. For image processing, Cell $P$ software (Olympus) was used. The antibody against neuronal class $\beta$-III-tubulin (TUJ1) was from Convance (mouse, 1:1000). As secondary antibody, anti-mouse IgG-Alexa 488 (1:1000) (Molecular Probes, Invitrogen) was used.

\subsection{Measurement of dopamine content}

For determination of endogenous intracellular dopamine, cells were differentiated for various time intervals in 24-well plates, lysed in $100 \mu \mathrm{l} 0.1 \mathrm{M}$ perchloric acid/100 $\mu \mathrm{M}$ ascorbic acid and subjected to one cycle of freeze-thawing. A small aliquot was used to determine the protein content by BCA protein assay kit (Pierce, Thermo Fisher Scientific). Samples were adjusted to equal protein contents and cell debris was removed by brief centrifugation at $15,000 \times g$. The supernatant was used for dopamine detection by a commercially available enzyme-linked immunoassay (IBL, Hamburg, Germany), according to the manufacturer's instructions. For an assessment of the unspecific background signal, homogenates of undifferentiated LUHMES (day 0 ; collected $12 \mathrm{~h}$ after seeding) were compared to rat primary glial cells or an equivalent protein amount of albumin that resulted in the same low basic signal.

\section{8. $\left[{ }^{3} H\right]-M P P^{+}$uptake assay}

Cells $(300,000 /$ well) grown in 24-well plates were washed $1 \times$ with Hank's Balanced Salt Solution (HBSS), containing $\mathrm{Ca}^{2+}, \mathrm{pH} 7.4$. LUHMES were treated with ascorbic acid, desferoxamine, zVADOMe-fmk, or Q-VD-OPh for $20 \mathrm{~min}$. Then $4625 \mathrm{~Bq} /$ well $(=15 \mathrm{nM})$ $\left.{ }^{3} \mathrm{H}\right]-\mathrm{MPP}^{+}$(3.1635 TBq/mmol stock solution; Perkin Elmer, Boston $\mathrm{MA})$ and $5 \mu \mathrm{M}\left[{ }^{1} \mathrm{H}\right]-\mathrm{MPP}^{+}$was added. The supernatants were collected after $20 \mathrm{~min}$, cells were gently washed $5 \times$ with warm HBSS and then lysed with PBS/0.1\% Triton X-100. Radioactivity in cell lysates and the respective supernatants was measured using a Beckman LS-6500 scintillation counter.

\subsection{Caspase activity detection}

Intracellular caspase activity was determined by lysis of cells in a hypotonic buffer ( $25 \mathrm{mM}$ Hepes, $5 \mathrm{mM} \mathrm{MgCl}$, $1 \mathrm{mM}$ EGTA, $0.1 \%$ Triton X-100, 1 mM PEFA block). Samples were added to substrate buffer ( 50 mM Hepes pH 7.4, 1\% sucrose, 0.1\% Chaps, 10 mM DTT) including $50 \mu \mathrm{M}$ of the substrate Ac-DEVD-afc (Biotrend, Köln,
Germany). Generation of free afc was followed by fluorescence measurement ( $\lambda_{\mathrm{ex}} 385 \mathrm{~nm} ; \lambda_{\mathrm{em}} 505 \mathrm{~nm}$ ) in intervals of $6 \mathrm{~min}$ for $1 \mathrm{~h}$ (Latta et al., 2000). Protein concentrations of the samples were determined by the BCA assay and samples were adjusted to equal total protein contents.

\subsection{ROS/radical detection assays}

Reactive oxygen species (ROS) were measured using DCF- $\mathrm{H}_{2-}$ DA (dichlorodihydrofluorescein-diacetate). Cells were incubated for $1 \mathrm{~h}$ with $1 \mu \mathrm{M}$ DCF- $\mathrm{H}_{2}$-DA before fluorescence was measured $\left(\lambda_{\text {ex }} 485 \mathrm{~nm} ; \lambda_{\text {em }} 538 \mathrm{~nm}\right)$.

The antioxidative potential of the compounds to be tested was monitored by their impact on the oxidation of dihydrorhodamine 123 (DHR 123; $1 \mu \mathrm{M}$ ) in combination with the peroxynitritegenerating compound Sin-1 $(50 \mu \mathrm{M})$ in $10 \mathrm{mM}$ K-phosphate buffer, $\mathrm{pH}$ 7.4. The test compounds and Sin- 1 were pre-incubated for $3 \mathrm{~min}$, DHR 123 was added for $20 \mathrm{~min}$ at $37^{\circ} \mathrm{C}$ and the fluorescence ( $\lambda_{\text {ex }} 485 \mathrm{~nm} ; \lambda_{\text {em }} 538 \mathrm{~nm}$ ) was determined in 96 -well plates. The superoxide $\left({ }^{\circ} \mathrm{O}_{2}^{-}\right)$scavenging capacity was investigated by a ${ }^{\bullet} \mathrm{O}_{2}{ }^{-}$generating system composed of xanthine oxidase $(2 \mathrm{mU} /$ $\mathrm{ml})$ plus its substrate hypoxanthine $(500 \mu \mathrm{M})$ in $10 \mathrm{mM} \mathrm{K}$ phosphate buffer, $\mathrm{pH}$ 7.4. Following a pre-incubation phase of $3 \mathrm{~min}$, DHE $(2.5 \mu \mathrm{M})$ was added for $20 \mathrm{~min}$ at $37^{\circ} \mathrm{C}$. To identify the $\cdot \mathrm{O}_{2}{ }^{-}$dependent oxidation of DHE, all samples were incubated in the absence or presence of SOD $(100 \mathrm{U} / \mathrm{ml})$, the difference of both fluorescence measurements $\left(\lambda_{\mathrm{ex}} 480 \mathrm{~nm} ; \lambda_{\mathrm{em}} 590 \mathrm{~nm}\right)$ represents the ${ }^{\bullet} \mathrm{O}_{2}{ }^{-}$dependent DHE oxidation (Schildknecht et al., 2011).

\subsection{Determination of mitochondrial shape in LUHMES using a mitochondrial fluorescent reporter cell line}

For the generation of mitochondria-targeted turbo Red Fluorescent Protein (tRFP), the mitochondrial targeting sequence from the cytochrome c oxidase subunit 8A (Accession NP_004065) and the tRFP gene from the plasmid pTripZ (purchased from Open Biosystems [Thermo Fisher Scientific, Inc.]) were cloned in frame. This fusion was inserted into the lentiviral vector $\mathrm{pHsCXW}$ (Leander Johansen et al., 2005) giving rise to phsCtRW. The gene is under control of the cytomegalovirus ( $C M V)$ immediate early promoter. Lentivirus production was carried out as previously described (Scholz et al., 2011). Subsequently, 20,000 proliferating LUHMES cells were seeded into a well of a 96-well plate, and were infected with $20 \mu$ l of 500 -fold concentrated (PEG-it ${ }^{\mathrm{TM}}$, System Biosciences) virus supernatant from HEK293FT producer cells for $12 \mathrm{~h}$, before they were passaged. A proliferating pool of stably transduced cells (93\% Mito-tRFP positive) was obtained and used for differentiations and imaging of differentiated cells. The cells were grown on glass cover slips (Menzel, Braunschweig, Germany), treated with compound or solvent control, and imaged with a CCD camera on an Olympus IX81 inverted epifluorescence microscope with a $100 \times, 1.4$ NA lens. Cell images from randomly selected fields were used for scoring of mitochondrial morphology by three observers blinded to the experimental conditions. At least 100 cells on three different cover slips per condition were classified according to mitochondrial shape. The percentage of cells with spread mitochondria allowing the distinction of individual thin longish mitochondrial parts (see example images in figures) was scored. Negative cells did not allow a clear distinction of individual mitochondria, as all mitochondria were clustered on one pole of the cell.

\subsection{Statistics}

All data were confirmed in at least three different experiments. Values are expressed as the mean $\pm \operatorname{SD}(n \geq 3)$. Data were analyzed by one-way ANOVA or Student's $t$-test as appropriate. Differences 
between treatment groups in multiple comparisons were determined by Dunnet's post hoc test (Graph Pad Prism software, San Diego, CA, USA). Means were considered statistically significant at $p<0.05$.

\section{Results}

3.1. Basic characterization of the MPP ${ }^{+}$cell death model in LUHMES neurons

The conditionally immortalized human dopaminergic cell line LUHMES, that has been recently characterized in detail
(Scholz et al., 2011) was used for all experiments. In this model, the differentiation of proliferating cells $(\mathrm{d} 0)$ to a homogeneous population of post-mitotic neurons (d6) takes 6 days. Within this period, the cells acquire the functional machinery for dopamine synthesis. We found that the intracellular dopamine content increased in parallel with the expression of the rate limiting enzyme of dopamine synthesis, tyrosine hydroxylase (TH) (Fig. 1A). The differentiated cells usually form a dense network of neurites that can easily exceed the length of the cell body by a factor of 10 . When d6 LUHMES were treated with $\mathrm{MPP}^{+}(5 \mu \mathrm{M})$ for $48 \mathrm{~h}$, staining for anti- $\beta$-III-tubulin indicated
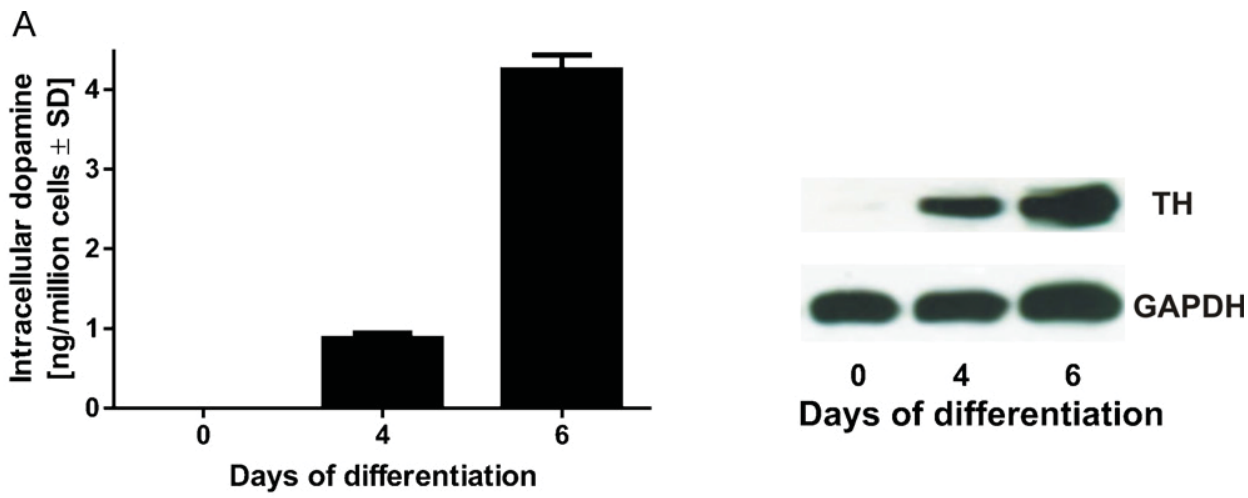

B

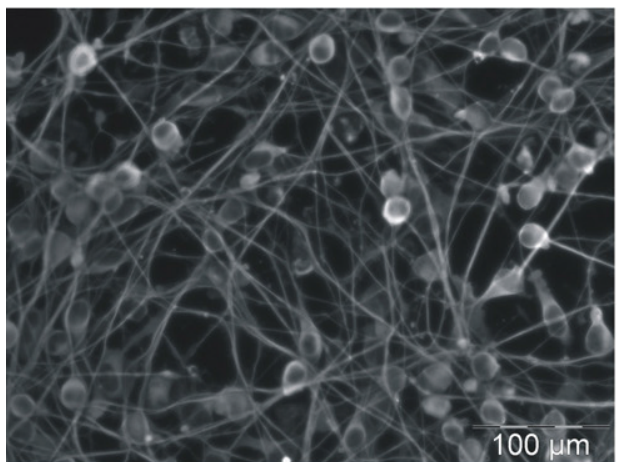

control

C

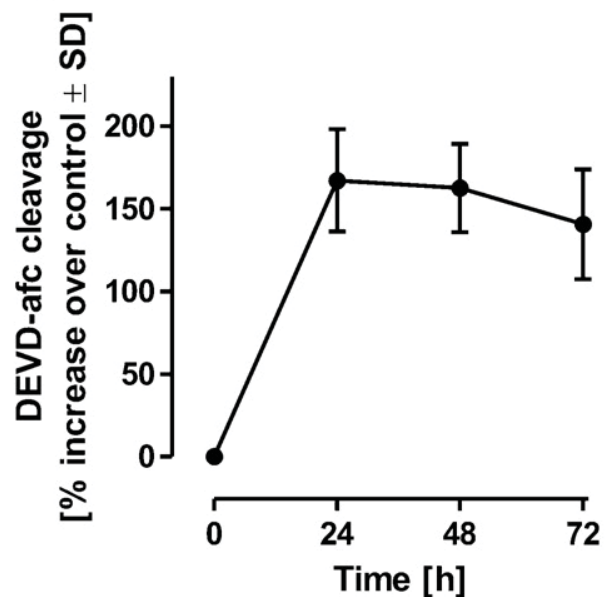

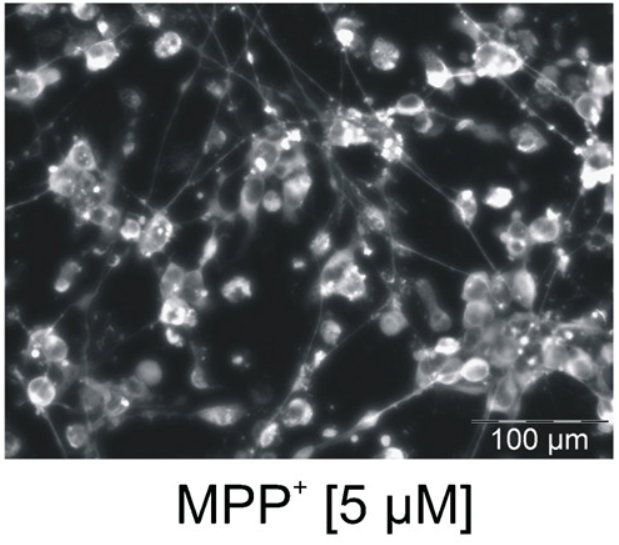

D

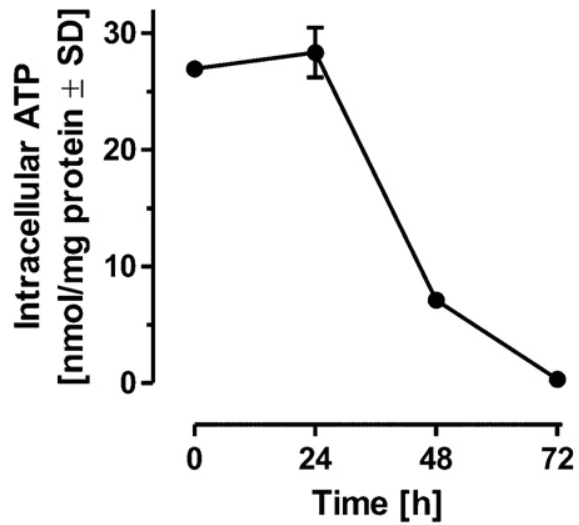

Fig. 1. Basic characteristics of the LUHMES/MPP ${ }^{+}$model. (A) Measurement of the intracellular dopamine content and quantification of tyrosine hydroxylase (TH) expression by Western blot on days 0,4 and $6\left(\mathrm{~d} 0, \mathrm{~d} 4\right.$, and d6) of differentiation. (B) Differentiated cells (d6) were incubated with $5 \mu \mathrm{M}$ MPP ${ }^{+}$or solvent (control) for 48 h, fixed and stained with an anti- $\beta$-III-tubulin antibody. (C) LUHMES were treated with $5 \mu \mathrm{M} \mathrm{MPP}^{+}$for the time intervals indicated and caspase-3-like activity (DEVD-afc cleavage) was detected. Solvent-treated cells were used as control. (D) Intracellular ATP levels under MPP ${ }^{+}$-treatment ( $5 \mu \mathrm{M}$ ) were measured in parallel. Data are means \pm SD for triplicate determinations. 
that the degeneration mostly involved neurite structures (Fig. 1B). After $72 \mathrm{~h}$, all cells were dead, and data obtained by the resazurin reduction assay always correlated with the measurement of LDH-release and with the number of dead cells. Untreated LUHMES survived for at least 6 additional days (d12) (data not shown; Schildknecht et al., 2009; Scholz et al., 2011). Studies on further parameters indicated that $\mathrm{MPP}^{+}$ $(5 \mu \mathrm{M})$ increased caspase activity before the intracellular ATP levels started to drop. Caspase-3 activity was maximally increased after $24 \mathrm{~h}$ (Fig. 1C), while general cell viability or ATP levels were not affected at this early time point. ATP dropped steeply and continuously between $24 \mathrm{~h}$ and $72 \mathrm{~h}$ (Fig. 1D).

\subsection{Inhibition of cell death signaling on mitochondrial level}

After the initial characterization of the cell death model, we used pharmacological agents interfering with cell death cascades at the level of mitochondria, and studied the effects on survival and cellular ATP levels. When we used a Bax channel blocker, we observed a concentration-dependent prevention of cell death triggered by $\mathrm{MPP}^{+}$(Fig. 2A). The ATP-depletion, triggered by $\mathrm{MPP}^{+}$, was not prevented by the inhibitor, and cells survived with significantly reduced ATP levels. There was even a trend (although not significant) to a further decrease of ATP levels in LUHMES exposed to $\mathrm{MPP}^{+}$plus the Bax channel blocker (Fig. 2B). The data are consistent with a continued block of mitochondrial respiration by $\mathrm{MPP}^{+}$, and a prevention of subsequent cell death events.

In a second approach, affecting cell death at the level of mitochondria in the LUHMES/MPP ${ }^{+}$model, the mitochondrial division inhibitor Mdivi-1 was used. A tightly controlled equilibrium of mitochondrial fission and fusion is required to maintain mitochondrial integrity, and excessive mitochondrial fragmentation is often harmful to neurons. We found here, that Mdivi-1 affected the mitochondrial morphology in LUHMES cells. Treatment with the compound resulted in a higher proportion of cells

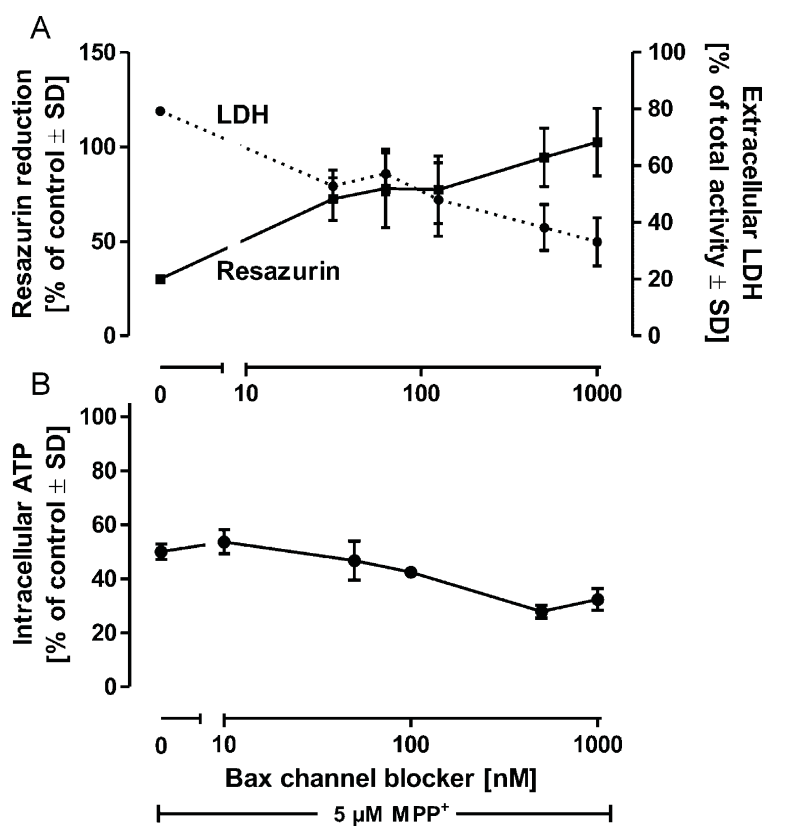

Fig. 2. Inhibition of cell death cascades at the level of mitochondria: Bax channel blockage. Differentiated LUHMES cells (d6) were exposed to $5 \mu \mathrm{M} \mathrm{MPP}^{+}$in the presence of various concentrations of a Bax channel blocker for $72 \mathrm{~h}$. (A) Viability was assessed by the resazurin reduction assay and by determination of LDHrelease. Solvent-treated cells were used as control. (B) Intracellular ATP levels were measured in parallel and normalized to cells treated with solvent only (control). Data are means \pm SD of quadruplicates of one experiment representative of three. with prolonged, spread mitochondria. In non-treated cells 30\% of mitochondria were spread, whereas Mdivi-1 treatment led to a significant increase to around 60\% (Fig. 3A). Such cells were also protected from $\mathrm{MPP}^{+}$-induced cell death (Fig. 3B). ATP-depletion was not changed by this treatment, i.e. the cells protected by Mdivi-1 showed a similar, or even higher ATP-depletion than parallel cultures treated with $\mathrm{MPP}^{+}$only (Fig. 3C). So, treatment with Mdivi-1 did not interfere with the primary biochemical action of $\mathrm{MPP}^{+}$, although it prevented subsequent cell death.

\subsection{Protection by various pharmacological agents in the LUHMES/ $\mathrm{MPP}^{+}$model}

We continued this study by examining whether uncoupling of cell death from ATP-depletion by $\mathrm{MPP}^{+}$was observed more generally. Therefore, a set of well-characterized and mechanistically diverse compounds likely to block $\mathrm{MPP}^{+}$-induced cell death in LUHMES was selected, to study their effect on ATP levels.

As one class of well-known (neuro)-protective compounds, caspase inhibitors were evaluated. LUHMES were treated with $\mathrm{MPP}^{+}$plus various concentrations of the caspase inhibitors zVADOMe-fmk and Q-VD-OPh, respectively. Then, the impact of the inhibitors on caspase activity (determined after $48 \mathrm{~h}$ ) and on cell death (determined after $72 \mathrm{~h}$ ) was compared. Concentrations (e.g. $1 \mu \mathrm{M}$ ) of inhibitors completely blocking caspase-3-like DEVDaseactivity did not improve cell viability. However, higher inhibitor concentrations $(20-100 \mu \mathrm{M})$ allowed protection against $\mathrm{MPP}^{+}$ toxicity (Fig. 4A and B). In order to gain information on the effect of caspase inhibitors on chromatin condensation in $\mathrm{MPP}^{+}$-treated LUHMES, nuclei were stained with Hoechst $\mathrm{H}-33342$ and scored for their shape. The two caspase inhibitors zVAD-OMe-fmk and Q-VDOPh both prevented chromatin condensation at high, but not at low concentrations (Fig. 4C). Notably, also the degeneration of neurites was completely prevented in $\mathrm{MPP}^{+}$-exposed LUHMES in the presence of $100 \mu \mathrm{M}$ zVAD-OMe-fmk or $25 \mu \mathrm{M}$ Q-VD-OPh (data not shown). These data suggest that proteases, which are sensitive to caspase inhibitors, strongly contribute to $\mathrm{MPP}^{+}$-induced cell death, neurite degeneration and chromatin condensation in LUHMES cultures.

As another class of neuroprotective compounds, we explored direct and indirect antioxidants. Since dichlorodihydrofluoresceindiacetate (DCF- $\mathrm{H}_{2}$-DA) was oxidized in the LUHMES/MPP ${ }^{+}$model, these data indicated an increased generation of reactive oxygen species (ROS) (Fig. 5A). Treatment with the antioxidant ascorbic acid improved the viability of LUHMES exposed to $\mathrm{MPP}^{+}$in a concentration dependent manner (Fig. 5B). Iron plays an important role in oxidative stress and dopamine toxicity. In line with this, we observed here that iron-trapping by desferoxamine effectively and potently reduced the toxicity of $\mathrm{MPP}^{+}$(Fig. 5C). As a further approach, we used the mixed lineage kinase (MLK) inhibitor CEP1347, and confirmed here the protection of LUHMES cells (Lotharius et al., 2005; Schildknecht et al., 2009) by this drug (Fig. 5D). To test the positive effect of the above drugs on cell viability by an independent approach, LDH-release was measured. Cells treated with $\mathrm{MPP}^{+}(5 \mu \mathrm{M})$ alone released most of their intracellular LDH. In contrast, LUHMES incubated in the presence of ascorbic acid $(100 \mu \mathrm{M})$, desferoxamine $(100 \mu \mathrm{M})$, or CEP1347 $(250 \mathrm{nM}$ ) displayed LDH release comparable to untreated control cells (Fig. 5E).

\subsection{Characterization of drugs preventing cell death of LUHMES}

Before the effects on ATP levels were characterized, we ascertained, that the chosen drugs showed the expected pharmacological profile, had widely different modes of action, and did not prevent the primary interaction of $\mathrm{MPP}^{+}$with mitochondria. 

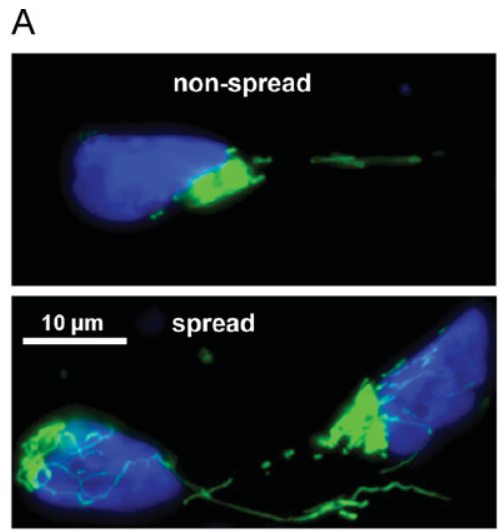

B

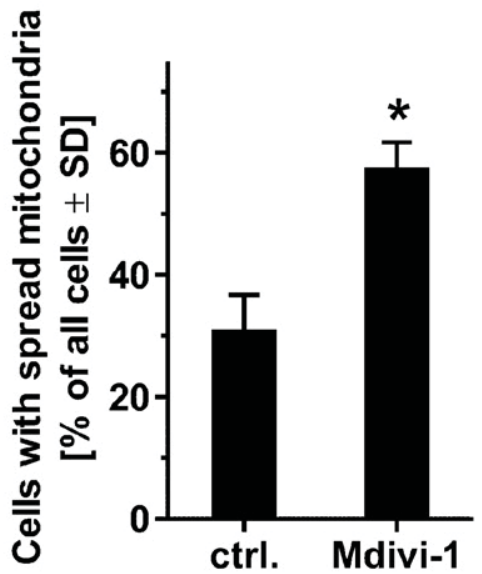

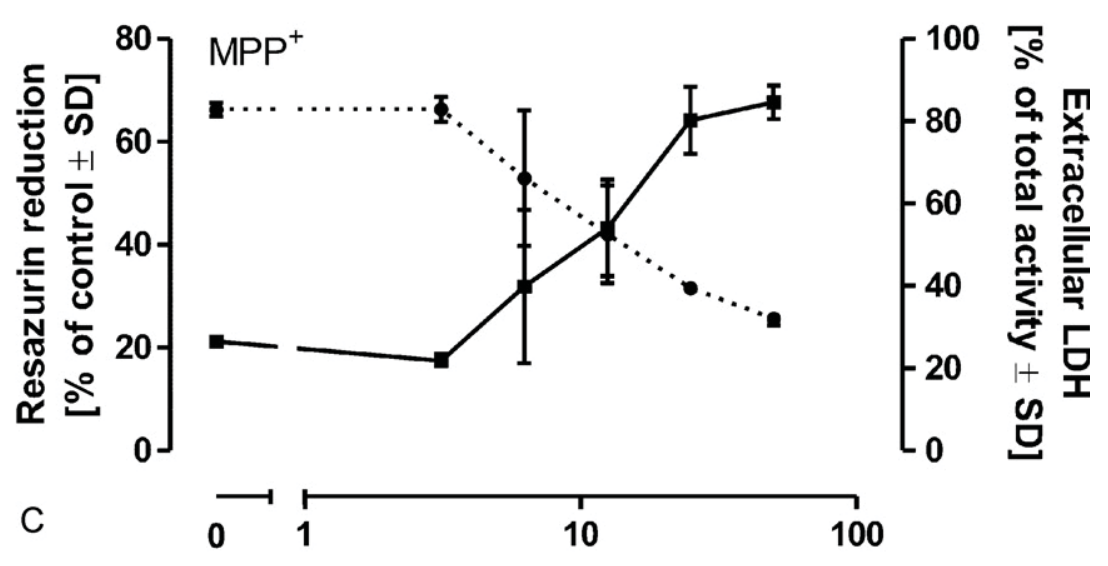

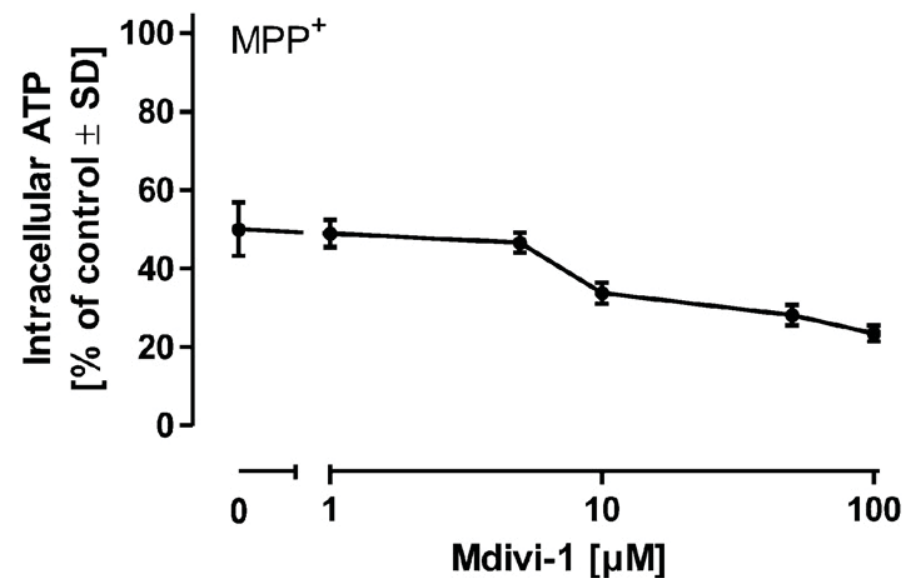

Fig. 3. Inhibition of cell death cascades at the level of mitochondria: inhibition of mitochondrial division. (A) LUHMES cells stably expressing mitochondria-targeted turboRFP were incubated with $100 \mu \mathrm{M}$ Mdivi-1 to study effects on the mitochondrial morphology. Cells were categorized as containing spread mitochondria or not (see example images for definition). $p<0.05$ for Mdivi-1-treated vs. solvent-treated cells. (B) Mdivi- 1 was applied in various concentrations in d6 LUHMES cells treated with MPP ${ }^{+}$and viability was assessed by the resazurin reduction assay and by determination of LDH-release. Solvent-treated cells were used as control. (C) Intracellular ATP levels were measured in parallel and normalized to cells treated with solvent only (control). Data are means \pm SD of quadruplicates.

First, we investigated a potential influence of the compounds on $\mathrm{MPP}^{+}$-uptake. Fully differentiated LUHMES were pre-treated with different concentrations of desferoxamine, ascorbic acid and CEP1347 for $20 \mathrm{~min}$. Also one of the caspase inhibitors, zVADOMe-fmk, was included in this characterization. After the drug equilibration phase, ${ }^{3} \mathrm{H}-\mathrm{MPP}^{+}$was added for $20 \mathrm{~min}$, and uptake of the radiolabel was measured. None of the compounds affected $\mathrm{MPP}^{+}$-uptake, and they had no effect on the intracellular accumulation of the mitochondrial inhibitor (Fig. 6A). We also used two assays to characterize the ROS (peroxynitrite and superoxide) scavenging capacity of our drug panel, to confirm that we are dealing with distinct modes of action. As expected, ascorbic acid was found to be active in both assays. As all other drugs were completely inactive, they seem to affect MPP by other modes of action, not related to a potentially unspecific ROS scavenging (Fig. 6B and C). 

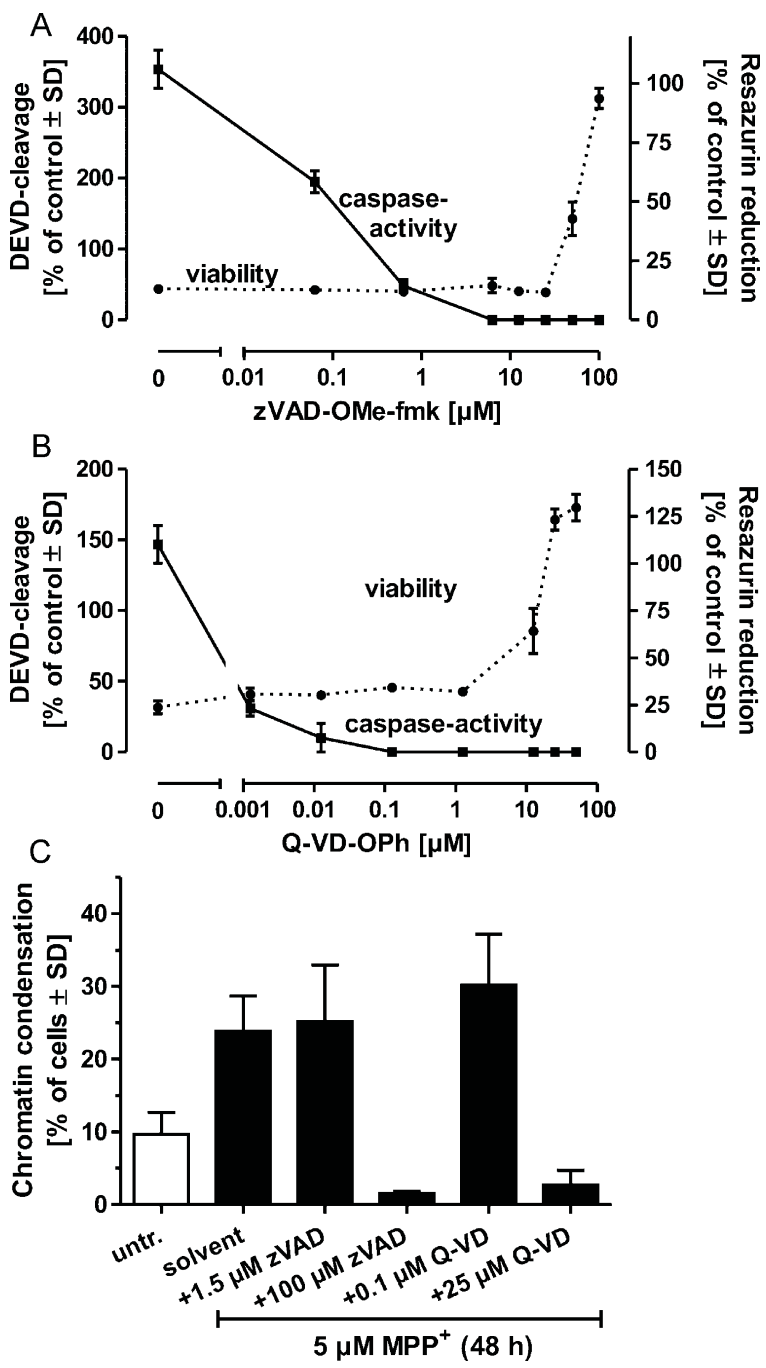

Fig. 4. Protection from $\mathrm{MPP}^{+}$-toxicity by caspase inhibitors. LUHMES (d6) were treated with $5 \mu \mathrm{M} \mathrm{MPP}^{+}$in the presence of the caspase inhibitors zVAD-OMe-fmk (A) or Q-VD-OPh (B). After $48 \mathrm{~h}$, intracellular DEVD-afc cleavage activity was detected. Cell viability (resazurin reduction) was determined after $72 \mathrm{~h}$ in parallel cultures. Solvent-treated cells were used as control. (C) Cells (d6) were treated with $5 \mu \mathrm{M} \mathrm{MPP}{ }^{+}$and different concentrations of caspase inhibitors for $48 \mathrm{~h}$, fixed, permeabilized and stained with the nuclear DNA marker Hoechst H-33342 $(1 \mu \mathrm{M})$ for $20 \mathrm{~min}$. Chromatin condensation, as measure of apoptosis, was assessed by manual counting and expressed as \% condensed nuclei of all nuclei in a given field. Data are means \pm SD for triplicate determinations.

\subsection{Uncoupling of cell death and ATP-depletion by pharmacologically} distinct mechanisms

The set of previously characterized inhibitors was now used to test whether uncoupling of ATP-depletion and cell death is a more general feature of the LUHMES/MPP ${ }^{+}$model. As it has been claimed recently in a consensus review on cell death measurements, different endpoints need to be measured to arrive at clear conclusions (Galluzzi et al., 2009). In addition to measurements of LDH-release and resazurin reduction, a further unrelated method was used. Staining with the membrane-impermeable dye SYTOX was performed to obtain results on cytoprotection on single cell level. This approach confirmed that zVAD-OMe-fmk (Fig. 7A) as well as ascorbic acid, desferoxamine and CEP1347 (data not shown) completely prevented cell death triggered by $\mathrm{MPP}^{+}$, and that the protected cells were still alive $48 \mathrm{~h}$ after the control cultures had died. ATP levels were measured in a time-resolved manner for $\mathrm{MPP}^{+}$-challenged cultures treated with zVAD-OMe- fmk or ascorbic acid. Also in the protected cells a strong drop of the ATP levels was observed. The initial drop was relatively similar in treated and untreated cultures. However, while the levels of ATP dropped by $90 \%$ and more in the LUHMES treated with $\mathrm{MPP}^{+}$for $72 \mathrm{~h}$, the levels in protected cells remained at about $30-40 \%$ of the original ATP content in healthy control cells (Fig. 7B). Thus, the two mechanistically diverse compounds rescued the cells without preventing primary ATP-depletion, but they blocked a secondary lethal drop in ATP levels. In a follow-up experiment, it was tested whether other protective drugs behaved similarly. Also Q-VD-OPh, CEP1347 and desferoxamine protected significantly from $\mathrm{MPP}^{+}-$ toxicity, but allowed a strong $(>50 \%)$ drop in ATP levels, as primary action of $\mathrm{MPP}^{+}$. Again, the final complete loss was prevented, and the ATP levels at $72 \mathrm{~h}$ after the onset of incubation were significantly higher than in the non-protected cells (Fig. 7C). In summary, the data suggest that $\mathrm{MPP}^{+}$leads to an ATP-depletion also in pharmacologically protected cells. Thus, the primary mode of action on mitochondrial energy generation appears to be unaffected by the drugs. However, since secondary cell death events that lead to a further drop in ATP are inhibited by the drugs, a complete loss of ATP is prevented, and a residual level of $30-40 \%$ is well compatible with cell survival (Latta et al., 2000).

\subsection{Uncoupling of cell death and ATP-depletion triggered by rotenone}

In a final experiment, we tested whether uncoupling of cell death and ATP-depletion was also observed when cells were exposed to rotenone ( $500 \mathrm{nM})$, another inhibitor of complex I of the mitochondrial respiratory chain. Rotenone induced cell death faster than $\mathrm{MPP}^{+}$, and after $48 \mathrm{~h}$, a majority of cells had died as indicated by a decreased reduction of resazurin, and the release of LDH into the extracellular space. Co-treatment with CEP1347 attenuated this cell death concentration-dependently, and significant protection was observed at $\geq 250 \mu \mathrm{M}$ of the kinase inhibitor (Fig. 8A and B). Parallel measurements of the cellular ATP content showed that ATP levels were reduced by more than $65 \%$ also in the protected cultures (Fig. 8C). Thus, uncoupling of primary ATPdepletion and cell death was also observed in this alternative model of mitochondrial inhibition.

\section{Discussion}

Parkinson's disease pathology has been related to defects in mitochondrial complex I for more than 20 years (Schapira et al., 1992). For instance, the highly selective inhibitor of mitochondrial complex I function, rotenone, can trigger key features of PD in rats (Betarbet et al., 2000). More recent findings show that MEF2, a key transcription factor affected in PD, controls the biosynthesis of complex I (She et al., 2011). An obligatory role of complex I inhibition for dopaminergic neuron degeneration has been claimed also after MPTP/MPP intoxication. For instance, damage triggered by MPTP was abolished by expression of a variant of complex I that does not bind $\mathrm{MPP}^{+}$(Barber-Singh et al., 2010; Richardson et al., 2007). Inhibition of mitochondrial respiration inhibits ATP production, and therefore energetic failure has been considered as cause of cell death triggered by $\mathrm{MPP}^{+}$. However, also other mechanisms have been suggested, based on the protection by intervening treatments or the modification of protein levels. These include the generation of reactive oxygen species (resulting in oxidative stress), the activation of stress kinases (including MLKs and c-jun $\mathrm{N}$-terminal kinase (JNK)), and the triggering of apoptotic mechanisms (comprising the induction of mitochondrial permeability transition, and the activation of caspases and other proteases). These events may occur downstream of ATP-depletion. A recent study suggested that such processes may also be triggered by rotenone and $\mathrm{MPP}^{+}$independent of ATP-depletion (Choi et al., 


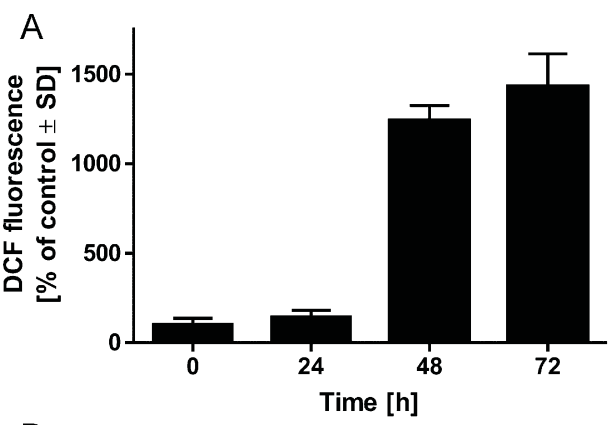

B
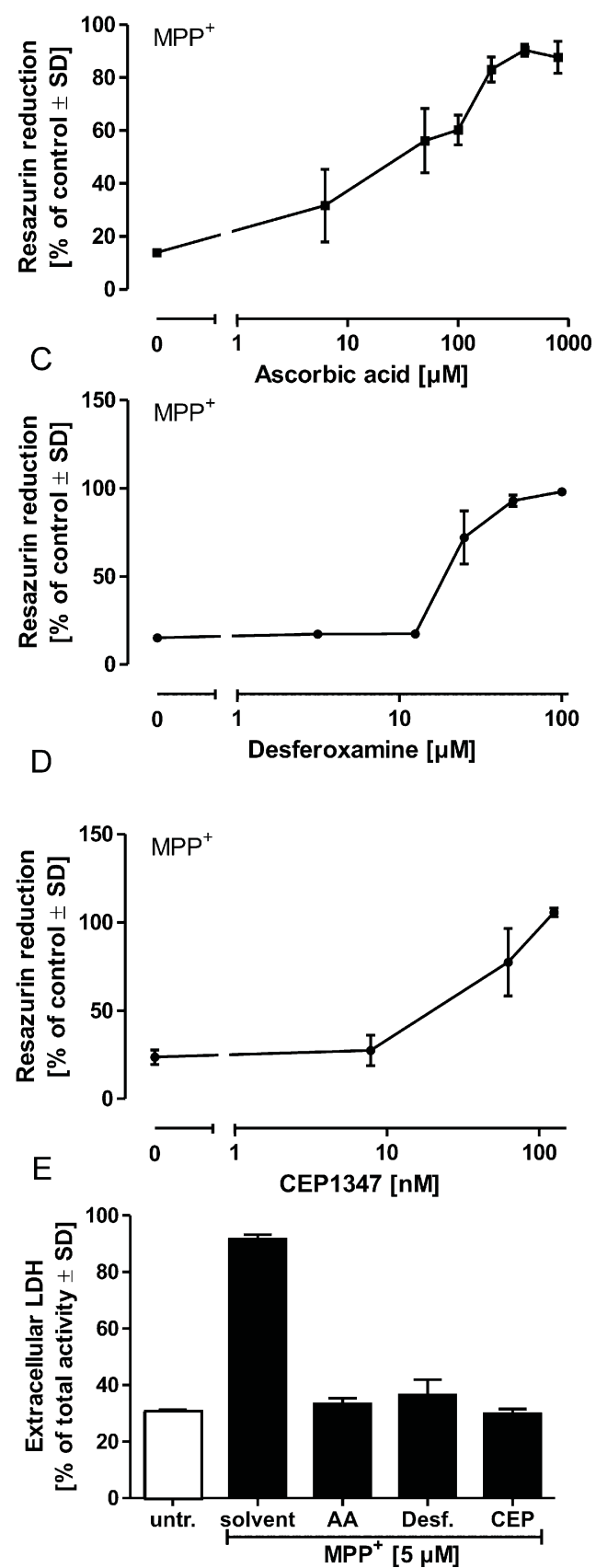

Fig. 5. Protection from $\mathrm{MPP}^{+}$-induced cell death. (A) Time-dependent ROS formation in d6 LUHMES, treated with $5 \mu \mathrm{M} \mathrm{MPP}^{+}$was assessed by the oxidation of dichlorodihydrofluorescein-diacetate (DCF- $\left.\mathrm{H}_{2}-\mathrm{DA}\right)$. Fluorescence of the oxidation product DCF in untreated cells $(0 \mathrm{~h}$, control) was defined as $100 \%$. (BD) Differentiated LUHMES cells (d6) were exposed to $5 \mu \mathrm{M} \mathrm{MPP}^{+}$in the presence of various concentrations of ascorbic acid (B), desferoxamine (C), or the mixed lineage kinase inhibitor CEP1347 (D) for $72 \mathrm{~h}$. Viability was assessed by the resazurin
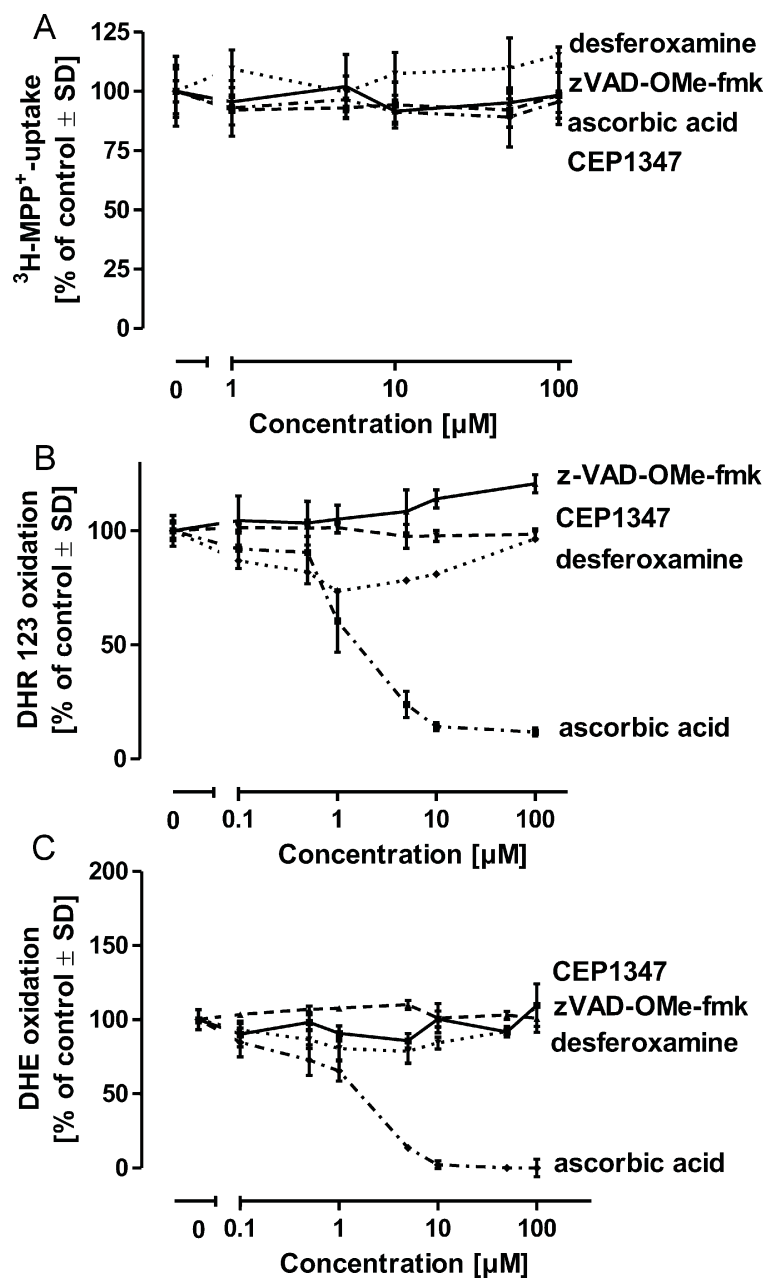

Fig. 6. Pharmacological characterization of various cell death inhibitors. (A) To investigate interference with $\mathrm{MPP}^{+}$-uptake, fully differentiated LUHMES (d6) were pre-treated with ascorbic acid, desferoxamine, zVAD-OMe-fmk or CEP1347 in the concentrations indicated for $20 \mathrm{~min}$. Then, $0.125 \mu \mathrm{Ci}^{3} \mathrm{H}-\mathrm{MPP}^{+}$in $5 \mu \mathrm{M}{ }^{1} \mathrm{H}-\mathrm{MPP}^{+}$was added for $20 \mathrm{~min}$, cells were gently washed four times and radioactivity was detected in the cell pellets. Solvent-treated cells were used as control. (B) To study direct peroxynitrite-scavenging capacities, zVAD-OMe-fmk, CEP1347, desferoxamine or ascorbic acid in the concentrations indicated, were pre-incubated with the peroxynitrite-donor Sin-1 ( $50 \mu \mathrm{M})$ in a cell-free system for $3 \mathrm{~min}$, followed by the addition of dihydrorhodamine (DHR 123; $1 \mu \mathrm{M}$ ). The oxidation of rhodamine was measured fluorometrically after $20 \mathrm{~min}$. (C) For studies on the superoxide $\left({ }^{\bullet} \mathrm{O}_{2}{ }^{-}\right)$ scavenging capacity, the test compounds were incubated with xanthine oxidase $(2 \mathrm{mU} / \mathrm{ml})$ and its substrate hypoxanthine $(500 \mu \mathrm{M})$. Dihydroethidium (DHE) $(2.5 \mu \mathrm{M})$ served as indicator for ${ }^{\bullet} \mathrm{O}_{2}{ }^{-}$. Fluorescence of ethidium was detected after an incubation period of 20 min. Data are means \pm SD for triplicate determinations.

2008). In this artificial model, using primary murine mesencephalic cell cultures lacking functionally assembled complex I, ATPdepletion could not be triggered by complex I inhibitors. In our study we addressed therefore the reverse situation, by allowing ATP-depletion in human dopaminergic neurons, but blocking other processes that have been associated with $\mathrm{MPP}^{+}$-induced cell death. This allowed us to clarify, whether ATP-depletion and cell death can be uncoupled. We found, that inhibition of complex I by $\mathrm{MPP}^{+}$ is compatible with cell survival in certain situations.

reduction assay and solvent-treated cells served as control. (E) For a direct comparison of the impact of MPP ${ }^{+}$, LUHMES were either left untreated (untr.) treated with $\mathrm{MPP}^{+}(5 \mu \mathrm{M})$ for $72 \mathrm{~h}$ alone (solvent) or in combination with ascorbic acid (AA; $100 \mu \mathrm{M}$ ), desferoxamine (Desf.; $100 \mu \mathrm{M}$ ), or CEP1347 (CEP; $250 \mathrm{nM}$ ). LDH release was detected as marker for cell viability. Data are means \pm SD of quadruplicates of one experiment representative of four. 

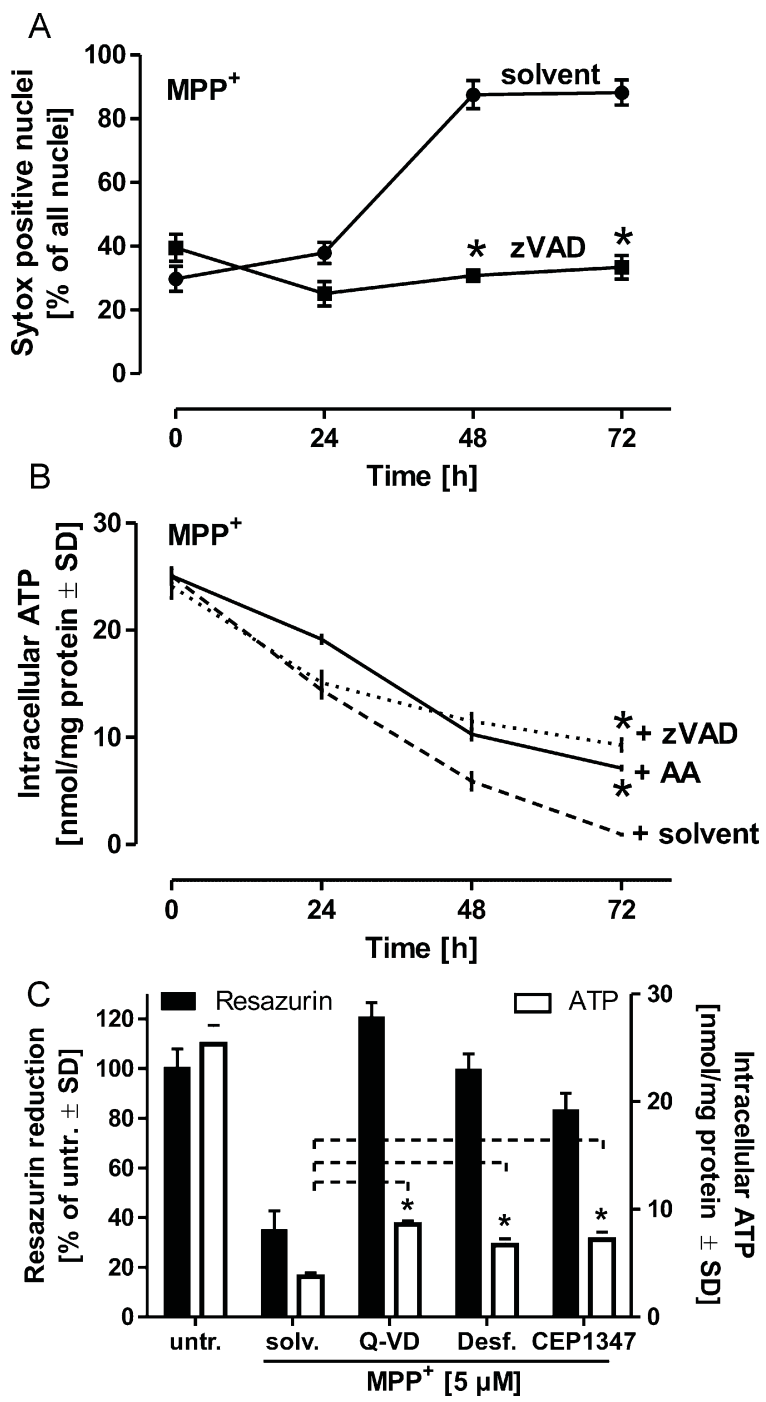

Fig. 7. Uncoupling of cell death and ATP loss. (A) LUHMES cells were incubated with $5 \mu \mathrm{M} \mathrm{MPP}{ }^{+}$in the presence of zVAD-OMe-fmk $(100 \mu \mathrm{M})$ and cell viability was assessed by SYTOX/Hoechst staining at different time points. SYTOX positive nuclei are given as percentage of all nuclei. (B) Intracellular ATP levels were measured in cell pellets after treatment with $5 \mu \mathrm{M} \mathrm{MPP}^{+}$plus solvent, $100 \mu \mathrm{M}$ zVAD-OMe-fmk or $1 \mathrm{mM}$ ascorbic acid for the time intervals indicated. (C) For the measurement of cell viability and corresponding ATP levels in untreated cells, cells were treated with

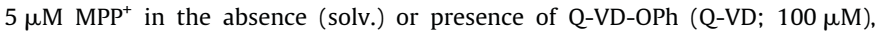
desferoxamine (Desf:; $100 \mu \mathrm{M}$ ) or CEP1347 (250 nM) for $72 \mathrm{~h}$. Data are means \pm SD of triplicates. ${ }^{*} p<0.05$ for compound (zVAD-OMe-fmk or ascorbic acid) against solvent in (A and B) and $p<0.05$ for ATP levels of compound (Q-VD-OPh, desferoxamine, CEP1347)-treated against solvent-treated cells.

Our data show that, although complex I activity of the mitochondrial respiratory chain may be the primary target of $\mathrm{MPP}^{+}$, death is only executed when pathways downstream of mitochondria are triggered. When such pathways, involving stress kinase signaling, protease activation, mitochondrial changes, and ROS formation were blocked, cells survived, although $\mathrm{MPP}^{+}$led to a strong ATP-depletion. This suggests, that neurons with an impairment of mitochondria may continue to function, if the generation of ROS or the activation of more downstream degenerative processes are blocked. In a complex tissue environment, growth factor signaling (Chung et al., 2005) or activation of survival signals such as protein kinase D1 (PKD1) activity (Asaithambi et al., 2011) may contribute to such resistance. This implies that pharmacological inhibition of neuronal death may still be possible in human disease, even when the initial etiological factors cannot be addressed.
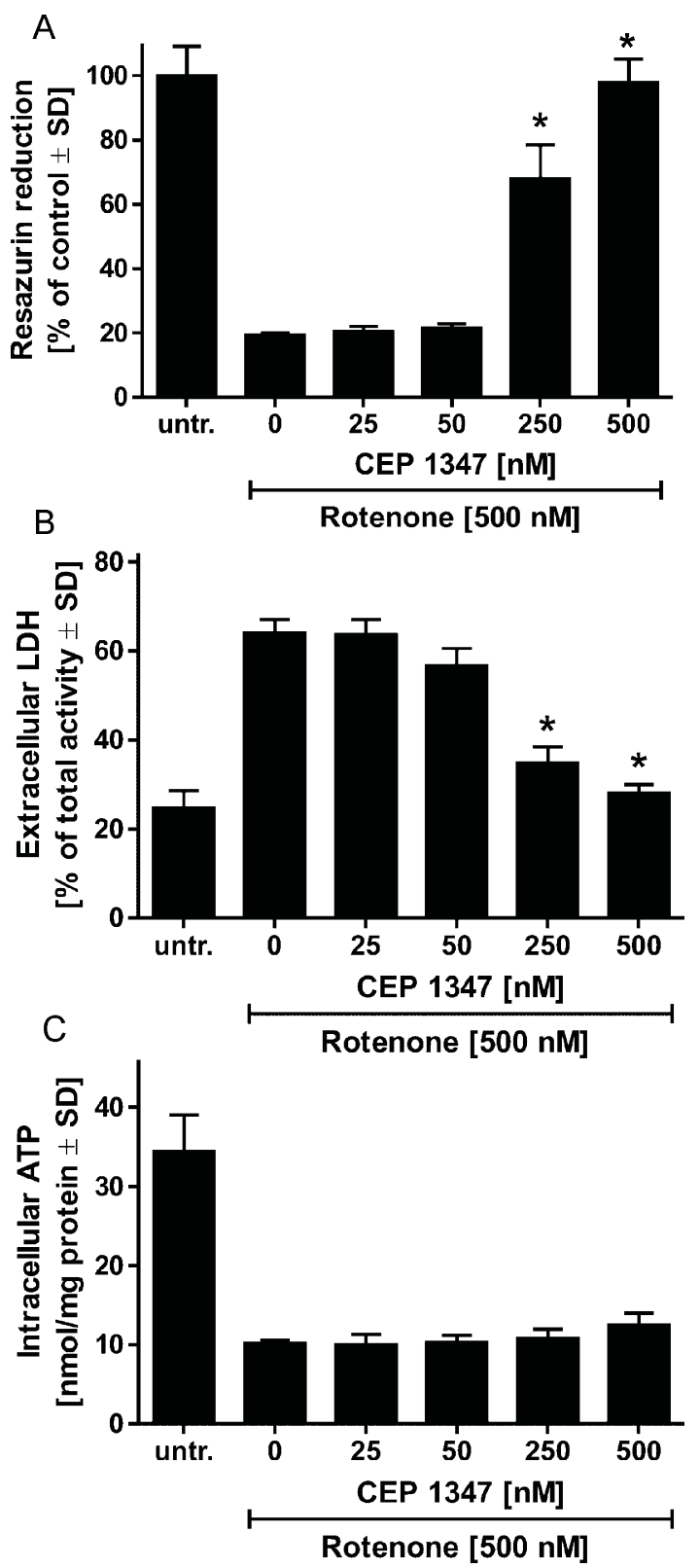

Fig. 8. Cell death and ATP-depletion in rotenone-toxicity. LUHMES (d6) were treated with $500 \mathrm{nM}$ rotenone and various concentrations of CEP1347 for $48 \mathrm{~h}$. (A) Resazurin reduction was measured and normalized to untreated control cells. Extracellular LDH activity (B) and intracellular ATP levels (C) were measured in parallel. Data are means \pm SD of quadruplicates. $p<0.05$ for rotenone plus 250 or $500 \mathrm{nM}$ CEP1347 vs. rotenone only.

In order to discriminate between ATP-dependent and independent pathways of $\mathrm{MPP}^{+}$toxicity, a set of well-established and functionally characterized neuroprotective compounds with different sites of action was applied in this study.

First, compounds known to preserve mitochondrial integrity in other settings were tested for uncoupling of ATP-depletion and cell death. Pharmacological inhibition of Bax channel formation prevented cell death, while the $\mathrm{MPP}^{+}$-dependent decline in ATP levels was not affected. For further investigations, the dynaminrelated GTPase (DRP) inhibitor Mdivi-1 was used (Cassidy-Stone et al., 2008). This compound is expected to prevent mitochondrial fission, an event often associated with neurodegeneration. For instance, reduced activities of the parkinsonism-related proteins Parkin (PARK2) and PINK1 (PARK6) are known to increase fission processes, leading to mitochondrial fragmentation (Cui et al., 2010; 
Dagda et al., 2009; Lutz et al., 2009). Treatment of LUHMES with Mdivi-1 led to a spread and prolongation of the mitochondrial network. The compound protected from $\mathrm{MPP}^{+}$-induced cell death. Similar to the situation with the Bax channel inhibitor, the MPP ${ }^{+}$dependent drop in ATP levels was not prevented. These findings suggested that ATP-depletion per se is not sufficient for the execution of cell death.

As next type of intervention strategy, we addressed caspases and related proteases. In the LUHMES model, we observed full caspase activation after $24 \mathrm{~h}$ of $\mathrm{MPP}^{+}$treatment and condensed chromatin was detected in nuclei after $48 \mathrm{~h}$. High concentrations of the pan-caspase inhibitors zVAD-OMe-fmk and Q-VD-OPh led to a full protection from $\mathrm{MPP}^{+}$. Also after this intervention, ATP was still strongly depleted by $>50 \%$. Thus, initial complex I inhibition by $\mathrm{MPP}^{+}$may lead to cellular malfunctions that induce Bax channel formation in the mitochondrial outer membrane. Released cytochrome c may then initiate caspase activation (Leist et al., 1999), and other processes may be triggered by oxygen radicals. Although, zVAD-OMe-fmk and Q-VD-OPh were useful in this study to provide further evidence that energy depletion and cell death can be uncoupled, their potential targets require some further discussion: low micromolar concentration of the compounds have been shown to block all residual caspase activity (Foghsgaard et al., 2001; Volbracht et al., 2001), and they also fully blocked the activity of caspase- 3 in MPP ${ }^{+}$treated LUHMES cells here. However, the concentrations required to prevent cell death were significantly higher than those required for full caspase inhibition. This correlates with earlier studies demonstrating that caspase inhibitors used at high concentrations inhibit other processes and proteases involved in programmed cell death, such as calpains and cathepsins (Berliocchi et al., 2005; Blomgren et al., 2007; Foghsgaard et al., 2001; Leist and Jäättelä, 2001; Schotte et al., 1999). In dopaminergic neurons, combined inhibition of caspases and oxidative stress has proven beneficial (Hansson et al., 2000), but direct anti-oxidative properties of the caspase inhibitors in high concentrations have been shown to be unlikely here. Also, the impact of zVAD-OMe-fmk on $\mathrm{MPP}^{+}$uptake into the cells was excluded. A more reasonable explanation for the protective effect in high concentrations is an unspecific inhibition of other proteases involved in caspase-independent mechanisms of programmed cell death.

Another downstream process we addressed for a role in uncoupling of ATP and cell death was oxidative stress. Inhibition of complex I by MPP ${ }^{+}$or rotenone can lead to the generation of free radicals by transfer of electrons directly to oxygen. The effects of dopamine autoxidation and complex I-dependent radical formation are made particularly detrimental to cells by the ironcatalyzed Fenton reaction. This has been thoroughly discussed in the literature as cause for selective dopaminergic neurodegeneration (Zhou et al., 2008). We therefore used the direct antioxidant ascorbic acid, or the iron chelator desferoxamine in the $\mathrm{MPP}^{+}$ LUHMES model. Pronounced protection was observed although ATP levels still dropped by $>50 \%$. We conclude from these findings that free radicals generated by $\mathrm{MPP}^{+}$treatment induce cell death of LUHMES similar to other models in the literature (Lotharius and O'Malley, 2000). Most importantly, block of these processes uncoupled cell death and ATP-depletion.

In a final approach, we used the MLK inhibitor CEP1347. This drug has been shown earlier to be protective in various models of general neuronal and dopaminergic degeneration (Boll et al., 2004; Lotharius et al., 2005; Müller et al., 2006; Schildknecht et al., 2009). It is generally assumed that this drug does not affect the energetic status of cells, but blocks its downstream detrimental consequences. Accordingly, we confirmed here the uncoupling of ATPdepletion and cell death by this independent approach. CEP1347 was also used to test whether similar effects were observed with rotenone. Also when this alternative complex I inhibitor was used, cell death was blocked while ATP-depletion occurred. This points to a possibly more general implication of our findings in the $\mathrm{MPP}^{+}$ model.

The possibility that cells may survive severe energy depletion may have implications for therapy and the understanding of disease pathogenesis, but also poses several questions to be addressed in the future. For instance, it is unclear yet whether the reduced, but still significant ATP production results from increased glycolysis or from residual mitochondrial function, and whether any of these may be further enhanced. Moreover, we did not address the question, whether ATP-depletion is associated with a change in energy charge (ratio of different adenosine nucleoside phosphates) of the cells, and whether there is a threshold of ATP levels not compatible anymore with cell survival. In the experiments shown here, ATP was depleted by $50-70 \%$. This would be consistent with findings in lymphocytes, hepatocytes, and neurons, that a reduction of intracellular ATP to about 30\% still allows survival and function (Latta et al., 2000; Leist et al., 1997; Volbracht et al., 1999). This is also supported by a large body of evidence from the field of hypoxia research, that suggests that neurons can survive under conditions of impaired mitochondrial respiration, provided that secondary events are blocked or counteracted, e.g. by preconditioning (Iadecola and Anrather, 2011). A further question would address the time period for which ATP-depletion may be tolerated. This may be interesting for discovery of mechanisms and pathways that expand this time span, similar to the block of TRPM7 channels in hypoxic neurons (Tymianski, 2011). Such research might eventually lead to explanations of the differential susceptibilities of different types of dopaminergic neurons to $\mathrm{MPP}^{+}$and ATP-depletion, and it would allow for the exploration and testing of new pharmacological intervention strategies.

\section{Conflict of interest statement}

The authors declare that there are no conflicts of interest.

\section{Acknowledgments}

We are indebted to many colleagues for valuable contributions and insightful discussions. We acknowledge in particular Regina Pape and Martina Adam, who provided excellent technical assistance. The work was facilitated by grants from the Doerenkamp-Zbinden Foundation, the Land Baden-Württemberg and the DFG (KoRS-CB).

\section{References}

Asaithambi A, Kanthasamy A, Saminathan H, Anantharam V, Kanthasamy AG. Protein kinase D1 (PKD1) activation mediates a compensatory protective response during early stages of oxidative stress-induced neuronal degeneration. Mol Neurodegener 2011;6:43.

Barber-Singh J, Seo BB, Matsuno-Yagi A, Yagi T. Protective role of rAAV-NDI1, serotype 5, in an acute MPTP mouse Parkinson's model. Parkinsons Dis 2010;2011:438370.

Behrouz B, Drolet RE, Sayed ZA, Lookingland KJ, Goudreau JL. Unique responses to mitochondrial complex I inhibition in tuberoinfundibular dopamine neurons may impart resistance to toxic insult. Neuroscience 2007;147:592-8.

Berliocchi L, Fava E, Leist M, Horvat V, Dinsdale D, Read D, et al. Botulinum neurotoxin $C$ initiates two different programs for neurite degeneration and neuronal apoptosis. J Cell Biol 2005;168:607-18.

Betarbet R, Sherer TB, MacKenzie G, Garcia-Osuna M, Panov AV, Greenamyre JT. Chronic systemic pesticide exposure reproduces features of Parkinson's disease. Nat Neurosci 2000;3:1301-6.

Bezard E, Przedborski S. A tale on animal models of Parkinson's disease. Mov Disord 2011;26:993-1002.

Blomgren K, Leist M, Groc L. Pathological apoptosis in the developing brain. Apoptosis 2007;12:993-1010.

Boll JB, Geist MA, Kaminski Schierle GS, Petersen K, Leist M, Vaudano E. Improvement of embryonic dopaminergic neurone survival in culture and after grafting into the striatum of hemiparkinsonian rats by CEP-1347. J Neurochem 2004;88:698-707. 
Braungart E, Gerlach M, Riederer P, Baumeister R, Hoener MC. Caenorhabditis elegans $\mathrm{MPP}^{+}$model of Parkinson's disease for high-throughput drug screenings. Neurodegener Dis 2004;1:175-83.

Cassidy-Stone A, Chipuk JE, Ingerman E, Song C, Yoo C, Kuwana T, et al. Chemical inhibition of the mitochondrial division dynamin reveals its role in Bax/Bakdependent mitochondrial outer membrane permeabilization. Dev Cell 2008:14:193-204.

Chan P, DeLanney LE, Irwin I, Langston JW, Di Monte D. Rapid ATP loss caused by 1methyl-4-phenyl-1,2,3,6-tetrahydropyridine in mouse brain. J Neurochem 1991;57:348-51.

Choi WS, Kruse SE, Palmiter RD, Xia Z. Mitochondrial complex I inhibition is not required for dopaminergic neuron death induced by rotenone, $\mathrm{MPP}^{+}$, or paraquat. Proc Natl Acad Sci U S A 2008;105:15136-41.

Chung CY, Seo H, Sonntag KC, Brooks A, Lin L, Isacson O. Cell type-specific gene expression of midbrain dopaminergic neurons reveals molecules involved in their vulnerability and protection. Hum Mol Genet 2005;14:1709-25.

Cui M, Tang X, Christian WV, Yoon Y, Tieu K. Perturbations in mitochondrial dynamics induced by human mutant PINK1 can be rescued by the mitochondrial division inhibitor mdivi-1. J Biol Chem 2010;285:11740-52.

Dagda RK, Cherra SJ 3rd, Kulich SM, Tandon A, Park D, Chu CT. Loss of PINK1 function promotes mitophagy through effects on oxidative stress and mitochondrial fission. J Biol Chem 2009;284:13843-55.

Di Monte DA. The environment and Parkinson's disease: is the nigrostriatal system preferentially targeted by neurotoxins. Lancet Neurol 2003;2:531-8.

DiMauro S, Schon EA. Mitochondrial disorders in the nervous system. Annu Rev Neurosci 2008;31:91-123.

Falsig J, Latta M, Leist M. Defined inflammatory states in astrocyte cultures: correlation with susceptibility towards CD95-driven apoptosis. J Neurochem 2004;88:18193.

Foghsgaard L, Wissing D, Mauch D, Lademann U, Bastholm L, Boes M, et al. Cathepsin B acts as a dominant execution protease in tumor cell apoptosis induced by tumor necrosis factor. J Cell Biol 2001;153:999-1010.

Galluzzi L, Aaronson SA, Abrams J, Alnemri ES, Andrews DW, Baehrecke EH, et al. Guidelines for the use and interpretation of assays for monitoring cell death in higher eukaryotes. Cell Death Differ 2009;16:1093-107.

Greenamyre JT, Sherer TB, Betarbet R, Panov AV. Complex I. Parkinson's disease. IUBMB Life 2001;52:135-41

Hansson O, Castilho RF, Kaminski Schierle GS, Karlsson J, Nicotera P, Leist M, et al. Additive effects of caspase inhibitor and lazaroid on the survival of transplanted rat and human embryonic dopamine neurons. Exp Neurol 2000;164:102-11.

Hirt UA, Leist M. Rapid, noninflammatory and PS-dependent phagocytic clearance of necrotic cells. Cell Death Differ 2003;10:1156-64.

Huber HJ, Duessmann H, Wenus J, Kilbride SM, Prehn JH. Mathematical modelling of the mitochondrial apoptosis pathway. Biochim Biophys Acta 2011:1813:608-15.

Hung HC, Lee EH. The mesolimbic dopaminergic pathway is more resistant than the nigrostriatal dopaminergic pathway to MPTP and MPP ${ }^{+}$toxicity: role of BDNF gene expression. Brain Res Mol Brain Res 1996;41:14-26.

Hung HC, Tao PL, Lee EH. 1-Methyl-4-phenyl-pyridinium $\left(\mathrm{MPP}^{+}\right)$uptake does not explain the differential toxicity of $\mathrm{MPP}^{+}$in the nigrostriatal and mesolimbic dopaminergic pathways. Neurosci Lett 1995;196:93-6.

Iadecola C, Anrather J. Stroke research at a crossroad: asking the brain for directions. Nat Neurosci 2011;14:1363-8.

Kaneko M, Saito Y, Saito H, Matsumoto T, Matsuda Y, Vaught JL, et al. Neurotrophic 3,9bis[(alkylthio)methyl]-and-bis(alkoxymethyl)-K-252a derivatives. J Med Chem 1997;40:1863-9.

Langston JW, Ballard P, Tetrud JW, Irwin I. Chronic Parkinsonism in humans due to a product of meperidine-analog synthesis. Science 1983;219:979-80.

Latta M, Künstle G, Leist M, Wendel A. Metabolic depletion of ATP by fructose inversely controls CD95- and tumor necrosis factor receptor 1-mediated hepatic apoptosis. J Exp Med 2000;191:1975-85.

Leander Johansen J, Dago L, Tornoe J, Rosenblad C, Kusk P. A new versatile and compact lentiviral vector. Mol Biotechnol 2005;29:47-56.

Leist M, Jäättelä M. Four deaths and a funeral: from caspases to alternative mechanisms. Nat Rev Mol Cell Biol 2001;2:589-98.

Leist M, Single B, Castoldi AF, Kuhnle S, Nicotera P. Intracellular adenosine triphosphate (ATP) concentration: a switch in the decision between apoptosis and necrosis. J Exp Med 1997;185:1481-6.
Leist M, Single B, Naumann H, Fava E, Simon B, Kuhnle S, et al. Nitric oxide inhibits execution of apoptosis at two distinct ATP-dependent steps upstream and downstream of mitochondrial cytochrome c release. Biochem Biophys Res Commun 1999;258:215-21

Leist M, Volbracht C, Fava E, Nicotera P. 1-Methyl-4-phenylpyridinium induces autocrine excitotoxicity, protease activation, and neuronal apoptosis. Mol Pharmacol 1998:54:789-801.

Lotharius J, Brundin P. Pathogenesis of Parkinson's disease: dopamine, vesicles and alpha-synuclein. Nat Rev Neurosci 2002;3:932-42.

Lotharius J, Falsig J, van Beek J, Payne S, Dringen R, Brundin P, et al. Progressive degeneration of human mesencephalic neuron-derived cells triggered by dopamine-dependent oxidative stress is dependent on the mixed-lineage kinase pathway. J Neurosci 2005;25:6329-42.

Lotharius J, O'Malley KL. The parkinsonism-inducing drug 1-methyl-4-phenylpyridinium triggers intracellular dopamine oxidation. A novel mechanism of toxicity. J Biol Chem 2000;275:38581-8.

Lutz AK, Exner N, Fett ME, Schlehe JS, Kloos K, Lammermann K, et al. Loss of parkin or PINK1 function increases Drp1-dependent mitochondrial fragmentation. J Biol Chem 2009;284:22938-51.

Müller GJ, Geist MA, Veng LM, Willesen MG, Johansen FF, Leist M, et al. A role for mixed lineage kinases in granule cell apoptosis induced by cytoskeletal disruption. J Neurochem 2006;96:1242-52.

Nicotra A, Parvez S. Apoptotic molecules and MPTP-induced cell death. Neurotoxicol Teratol 2002;24:599-605.

Orrenius S, Nicotera P, Zhivotovsky B. Cell death mechanisms and their implications in toxicology. Toxicol Sci 2011;119:3-19.

Richardson JR, Caudle WM, Guillot TS, Watson JL, Nakamaru-Ogiso E, Seo BB, et al. Obligatory role for complex I inhibition in the dopaminergic neurotoxicity of 1 methyl-4-phenyl-1,2,3,6-tetrahydropyridine (MPTP). Toxicol Sci 2007;95:196204.

Schapira AH. Complex I: inhibitors, inhibition and neurodegeneration. Exp Neurol 2010;224:331-5

Schapira AH, Mann VM, Cooper JM, Krige D, Jenner PJ, Marsden CD. Mitochondrial function in Parkinson's disease. The Royal Kings and Queens Parkinson's Disease Research Group. Ann Neurol 1992;32(Suppl.):S116-24.

Schildknecht S, Pape R, Müller N, Robotta M, Marquardt A, Bürkle A, et al. Neuroprotection by minocycline caused by direct and specific scavenging of peroxynitrite. J Biol Chem 2011;286:4991-5002.

Schildknecht S, Pöltl D, Nagel DM, Matt F, Scholz D, Lotharius J, et al. Requirement of a dopaminergic neuronal phenotype for toxicity of low concentrations of 1-methyl4-phenylpyridinium to human cells. Toxicol Appl Pharmacol 2009;241:23-35.

Scholz D, Pöltl D, Genewsky A, Weng M, Waldmann T, Schildknecht S, et al. Rapid, complete and large-scale generation of post-mitotic neurons from the human LUHMES cell line. J Neurochem 2011;119:957-71.

Schon EA, Przedborski S. Mitochondria: the next (neurode)generation. Neuron 2011;70:1033-53

Schotte P, Declercq W, Van Huffel S, Vandenabeele P, Beyaert R. Non-specific effects of methyl ketone peptide inhibitors of caspases. FEBS Lett 1999;442:117-21.

She H, Yang Q, Shepherd K, Smith Y, Miller G, Testa C, et al. Direct regulation of complex I by mitochondrial MEF2D is disrupted in a mouse model of Parkinson disease and in human patients. J Clin Invest 2011;121:930-40.

Stephans SE, Miller GW, Levey AI, Greenamyre JT. Acute mitochondrial and chronic toxicological effects of 1-methyl-4-phenylpyridinium in human neuroblastoma cells. Neurotoxicology 2002:23:569-80.

Sundstrom E, Samuelsson EB. Comparison of key steps in 1-methyl-4-phenyl-1,2,3,6tetrahydropyridine (MPTP) neurotoxicity in rodents. Pharmacol Toxicol 1997;81: 226-31.

Tymianski M. Emerging mechanisms of disrupted cellular signaling in brain ischemia. Nat Neurosci 2011;14:1369-73.

Volbracht C, Leist M, Kolb SA, Nicotera P. Apoptosis in caspase-inhibited neurons. Mol Med 2001;7:36-48.

Volbracht C, Leist M, Nicotera P. ATP controls neuronal apoptosis triggered by microtubule breakdown or potassium deprivation. Mol Med 1999;5:477-89.

von Bohlen und Halbach O. Modeling neurodegenerative diseases in vivo review. Neurodegener Dis 2005;2:313-20.

Zhou C, Huang Y, Przedborski S. Oxidative stress in Parkinson's disease: a mechanism of pathogenic and therapeutic significance. Ann N Y Acad Sci 2008;1147:93-104. 